\title{
Experimental analysis of the use of R1234yf and R1234ze(E) as drop-in alternatives of R134a in a water-to-water heat pump
}

\author{
Luigi Pietro Maria Colombo, Andrea Lucchini, Luca Molinaroli* \\ Dipartimento di Energia, Politecnico di Milano, Via Lambruschini 4, 20156, Milano, Italy
}

\begin{abstract}
In the present paper, the experimental results of the use of R1234yf and R1234ze(E) as dropin alternatives of R134a in a water-to-water heat pump are discussed. The heat pump is firstly tested with R134a, to establish the baseline performance, and, then, is tested with the two abovementioned refrigerants considering the same compressor shaft rotational frequency and the same outlet temperatures of the secondary fluids from the evaporator and the condenser. The obtained results show that, compared to the R134a, the use of R1234yf leads to a reduction of the heating capacity and of the COP up to $9.80 \%$ and $7.39 \%$ respectively, whereas with the use of R1234ze(E) the capacity reduction achieves a maximum of $33.82 \%$ while a COP variation in the range $-12.27 \%$ to $+4.32 \%$ is found. A second group of tests is carried out varying the rotational frequency of the compressor shaft with the aim of matching the baseline R134a heating capacity. The results indicate an increase in the shaft rotational frequency up to $16 \%$ with R1234yf and up to $50 \%$ with R1234ze(E) which, however, leads to a maximum reduction of the heat pump COP respectively equal to $7.38 \%$ and to $18.11 \%$.
\end{abstract}

Keywords: COP, Heat pump, Heating capacity, R1234yf, R1234ze(E), R134a

\section{Nomenclature}

$c_{P} \quad$ isobaric heating capacity $\left[\mathrm{kJ} \cdot \mathrm{s}^{-1} \cdot \mathrm{K}^{-1}\right]$

$f \quad$ frequency $[\mathrm{Hz}]$

*Corresponding author. Tel.: +3902 23993872, Fax: +3902 23993913

Email address: luca.molinaroli@polimi.it (Luca Molinaroli) 
$h \quad$ enthalpy $\left[\mathrm{kJ} \cdot \mathrm{kg}^{-1}\right]$

$\dot{m} \quad$ mass flow rate $\left[\mathrm{kg} \cdot \mathrm{s}^{-1}\right]$

$N \quad$ number of uncorrelated input quantities [dimensionless]

$\dot{Q} \quad$ heat flow rate $[\mathrm{W}]$

$T \quad$ temperature $[\mathrm{K}]$

$t_{95} \quad$ Student test multiplier at $95 \%$ confidence level [dimensionless]

$u \quad$ uncertainty [various]

$\dot{W} \quad$ power $[\mathrm{W}]$

$x \quad$ generic measured variable [various]

$y \quad$ generic calculated variable [various]

\section{Greek symbols}

$\sigma_{\bar{x}} \quad$ standard deviation of the mean value of the collected samples [various]

\section{Subscripts}

$\begin{array}{ll}\text { COMP } & \text { compressor } \\ \text { COND } & \text { condenser } \\ \text { EVAP } & \text { evaporator or evaporating } \\ \text { G } & \text { water-ethylene glycol mixture } \\ \text { INST } & \text { Instrumental } \\ \text { IN } & \text { inlet } \\ \text { OUT } & \text { outlet }\end{array}$




$\begin{array}{ll}R & \text { refrigerant } \\ \text { SHAFT } & \text { shaft } \\ \text { SUP } & \text { superheating } \\ & \\ W & \text { water }\end{array}$

\section{Introduction}

The recent EU 517/2014 regulation (European Union, 2014) and the Kigali amendment (United Nations, 2016) to the Montreal Protocol have introduced constraints that force the air conditioning and refrigeration industry to find new refrigerants able to cope with more and more severe limits on Global Warning Potential (GWP). As a consequence, in the last years, new refrigerants have been continuously introduced and the need of testing them in vapour compression systems to analyse their performance arises. Among them, the HydroFluoroOlefins (HFOs) R1234yf and R1234ze(E) have gained attention as substitutes of R134a.

The use of HFOs in vapour compression systems has attracted a lot of attention in the recent scientific literature. Both experimental and numerical studies has been carried out with the aim of assessing the performance of these alternative refrigerants and comparing them with R134a.

From the experimental point of view, Zilio et al. (2011) analysed the performance of an air-toair vapour compression system (i.e. a system in which air is used as secondary fluid both at the evaporator and at the condenser) for mobile air conditioning working with R134a and R1234yf. They found that the drop-in operation of the system using R1234yf lead to a significant capacity reduction, in the range $12 \%$ to $24 \%$, and a slightly lower COP reduction, in the range $2 \%$ to 19\%. Navarro-Esbrí and co-workers (Navarro-Esbrí et al., 2013a,b) carried out an extensive experimental analysis of the use of R1234yf in a water-to-water (i.e. a system in which water is used as secondary fluid both at the evaporator and at the condenser) vapour compression system in a drop-in application. They analysed the influence of evaporating temperature, condensing temperature, internal heat exchanger use, superheating degree and compressor drive frequency. They found that the use of R1234yf leads to an overall reduction of the cooling capacity, in the range 
$4.36 \%$ to $13.46 \%$, and of the COP, in the range $5.60 \%$ to $27.89 \%$, with larger differences at low evaporating or condensing temperatures. Moreover, R1234yf benefited more than R134a from the use of internal heat exchanger since the decrease in cooling capacity and COP is reduced in the range $2 \%$ to $6 \%$, while the influence of different superheating set-points or different compressor drive frequencies was negligible. Mota-Babiloni et al. (2014) experimentally assessed the performance of a water-to-water vapour compression system in a drop-in application of R134a, R1234yf and R1234ze(E). Three evaporating temperatures in the range $260 \mathrm{~K}$ to $280 \mathrm{~K}$, three condensing temperatures in the range $310 \mathrm{~K}$ to $330 \mathrm{~K}$ were considered for a total of 9 experimental points per fluid. Additional 9 points were tested adding an internal heat exchanger to the system. Overall, it was observed that the use of R1234yf resulted in a cooling capacity reduction up to $13.71 \%$ and a COP reduction up to $10.50 \%$, whereas the use of $\mathrm{R} 1234 \mathrm{ze}(\mathrm{E})$ led to a cooling capacity reduction up to $33.68 \%$ and a COP reduction up to $8.40 \%$. Similarly to R1234yf, a R1234ze(E) system was demonstrated to benefit from the use of a liquid line - suction line heat exchanger more than a R134a system (Mota-Babiloni et al., 2015). Sethi et al. (2016) compared the performance of a vapour compression system working with R134a, R1234yf and R1234ze(E) in a typical refrigeration application. They found that the use of R1234yf leads up to $3 \%$ cooling capacity reduction and up to $4 \% \mathrm{COP}$ reduction whereas the use of $\mathrm{R} 1234 \mathrm{ze}(\mathrm{E})$ required a compressor with $75 \%$ larger displacement that leads to an increase in the cooling capacity up to $9 \%$ and a COP reduction up to $16 \%$. A theoretical analysis dealing with the redesign of the evaporator circuitry and dimension was carried out finding that the efficiency of the system may increase, reaching the baseline values, with an optimized heat exchanger. Sánchez et al. (2017) experimentally compared six different refrigerants in a direct drop-in application in a water-to-water system and, among them, R134a, R1234yf and R1234ze(E) were considered. They considered two evaporating temperatures, namely $-10^{\circ} \mathrm{C}$ and $0^{\circ} \mathrm{C}$, and three condensing temperatures, namely $25^{\circ} \mathrm{C}$, $35^{\circ} \mathrm{C}$ and $45^{\circ} \mathrm{C}$, finding that the cooling capacity and the COP of the system using R1234yf were respectively reduced in the range $4.5 \%$ to $8.6 \%$ and $8.3 \%$ to $11.0 \%$ with respect to the R134a baseline. Instead, with R1234ze(E), the cooling capacity and COP reduction were between $22.9 \%$ and $26.6 \%$ and between $2.8 \%$ and $13.0 \%$. Finally, Devecioglu and Oruç (2018) experimentally analysed the influence of an internal heat exchanger in an air-to-air vapour compression system 
in which R1234yf and R1234ze(E) were used as drop-in substitutes of R134a. They found that the cooling capacity of the system using R134a is higher than that of the system using R1234yf which, in turn, is higher than that obtained with R1234ze(E). The capacity increased using the internal heat exchanger with respect to the baseline configuration without it. Regarding the COP, R134a was the best refrigerants but R1234ze(E) performed better than R1234yf. Again, the use of the internal heat exchanger led to increased performance of the vapour compression system.

Besides experimental investigations, numerical studies of the use of R1234yf and R1234ze(E) are available too in the scientific literature. Jarall (2012) carried out a theoretical analysis of the use of R1234yf in a water-to-water system showing that R1234yf exhibits lower pressure ratio, refrigerant temperature at compressor discharge and COP. The further experimental study confirmed these findings and showed a reduction of cooling capacity and COP in the range $3.4 \%$ to $13.7 \%$ and $0.35 \%$ to $11.88 \%$. Molés et al. (2014) analysed several configurations of vapour compression system with the aim of improving its performance when HFOs are used as refrigerant. They found that R1234yf and R1234ze(E) benefit more than R134a from the use of an expander, an ejector or an internal heat exchanger. Jankovic et al. (2015) compared R134a, R1234yf and R1234ze(E) in a vapour compression system by means of a validated simulation tool. They found that, under the same evaporating and condensing temperatures, the cooling capacity of both HFOs is lower than that of R134a with reduction equal to about $6 \%$ for R1234yf and $27 \%$ for R1234ze(E). On the other side, the COP of the system was about $1 \%$ lower for R1234ze(E) and from $2 \%$ to $5 \%$ lower for R1234yf. Vice-versa, under the same cooling medium conditions, i.e. same inlet and outlet temperatures at the condenser, R1234yf was found to perform worse than R134a both with respect to cooling capacity, from 5\% to $9 \%$ reduction, and COP, with reduction in the range $7 \%$ to $10 \%$. On the other side, with respect to R134a R1234ze(E) showed lower cooling capacity, about $25 \%$ less, but higher COP, with increment in the range $4 \%$ to $7 \%$. An increase of the compressor shaft frequency in the range $5 \%$ to $10 \%$ with R1234yf and $34 \%$ to $39 \%$ with R1234ze(E) was found to be mandatory in order to restore the R134a cooling capacity. However, in these operating conditions, a reduction of the isentropic COP as high as $12 \%$ with R1234yf and up to 5\% with R1234ze(E) arose. Finally, Nawa et al. (2017) carried out an extensive numerical study with a validate simulation model of the use of R1234yf and R1234ze(E) as substitutes of R134a in heat 
pump water heaters. They concluded that the two HFOs lead to performances (first hour rating, unified energy factor and COP) slightly lower than those obtained with R134a. The charge of the system was found similar whereas the refrigerant temperature at compressor discharge was higher for R134a but R1234ze(E) required a larger compressor to overcome its lower volumetric heating capacity.

All the aforementioned studies provide valuable information about the use of R1234yf and $\mathrm{R} 1234 \mathrm{ze}(\mathrm{E})$ as R134a alternatives in vapour compression systems. The present study is aimed at contributing to this general discussion, presenting the results of an experimental campaign carried out on a small water-to-water vapour compression system designed for this purpose. With respect to the studies available in the open literature, the present paper is focused on a heat pump system, rather than a refrigerating system, and considers a broad range of operating conditions that are typical of heat pump systems for residential application. Especially at the condenser, low, medium and high temperatures of the secondary fluids are analysed in order to find which HFO is the most appropriate alternative to R134a depending on the temperature level of the supplied heat. Additionally, from the methodology point of view, the experimental results are obtained keeping constant the inlet and/or the outlet temperatures of the secondary fluids that flow through the evaporator and the condenser rather than fixing the evaporating and the condensing temperature, as done in most of the experimental works reviewed above. According to Jankovic et al. (2015), this testing method leads to "a more realistic drop-in replacement analysis" since, in any heat pump system, given the compressor shaft rotational frequency, the evaporating and the condensing temperatures are not predetermined values but depend on the heat exchangers features such as heat transfer areas and type (air, water or brine), mass flow rate and temperature of the secondary fluids.

\section{Experimental set-up and methodology}

\subsection{Experimental set-up}

The layout of the experimental set-up used to assess the performance of R134a, R1234yf and $\mathrm{R} 1234 z e(\mathrm{E})$ in a drop-in application is shown in Figure 1.

The test rig mimics a single-stage water-to-water heat pump and basically consists of three different loops: the refrigerant loop black line, the cold water + ethylene glycol loop blue line 


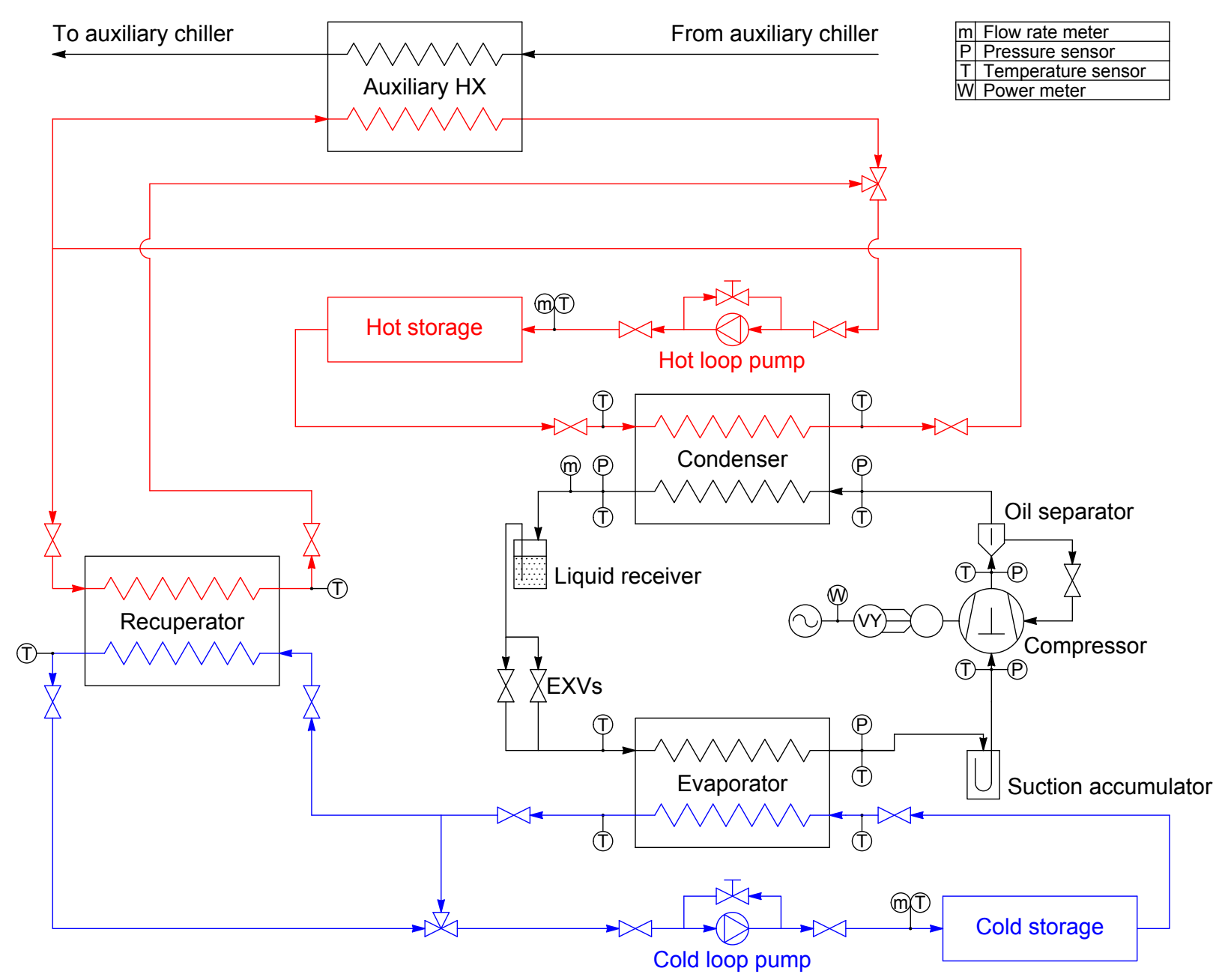

Figure 1 - Layout of the experimental set-up. 
and the hot water loop red line. The main characteristics of the components the experimental set-up consists of are summarised in Table 1.

Table 1 - Main characteristics of the components used in the experimental set-up.

\begin{tabular}{|c|c|c|}
\hline Component & Parameter & Range \\
\hline \multirow{4}{*}{ Compressor } & Swept volume@ @ $50 \mathrm{~Hz}$ & $13.15 \mathrm{~m}^{3} \cdot \mathrm{h}^{-1}$ \\
\hline & Shaft rotational frequency & $30 \mathrm{~Hz}-87 \mathrm{~Hz}$ \\
\hline & Oil & POE ISO 32 \\
\hline & Oil charge & $1.1 \mathrm{dm}^{3}$ \\
\hline \multirow{2}{*}{ Condenser } & Height x Width x Depth & $289 \mathrm{~mm}$ x $119 \mathrm{~mm}$ x $93.6 \mathrm{~mm}$ \\
\hline & Number of plates & 40 \\
\hline \multirow{2}{*}{ Evaporator } & Height $x$ Width $x$ Depth & $376 \mathrm{~mm} \times 119 \mathrm{~mm} \times 71.2 \mathrm{~mm}$ \\
\hline & Number of plates & 30 \\
\hline \multirow{2}{*}{ Expansion valve } & Capacity range & $1200 \mathrm{~W}-12000 \mathrm{~W}$ \\
\hline & Capacity range & $1690 \mathrm{~W}-16900 \mathrm{~W}$ \\
\hline Liquid receiver & Volume & $2.8 \mathrm{dm}^{3}$ \\
\hline Suction accumulator & Volume & $2.33 \mathrm{dm}^{3}$ \\
\hline \multirow[t]{2}{*}{ Oil separator } & Type & Coalescence \\
\hline & Volume & $2.8 \mathrm{dm}^{3}$ \\
\hline \multirow{3}{*}{ Pumps } & Nominal flow rate & $28.7 \mathrm{~m}^{3} \cdot \mathrm{h}^{-1}$ \\
\hline & Nominal head & $160 \mathrm{kPa}$ \\
\hline & Shaft rotational frequency & $16 \mathrm{~Hz}-58 \mathrm{~Hz}$ \\
\hline \multirow{2}{*}{ Recuperator } & Height $x$ Width $x$ Depth & $193 \mathrm{~mm}$ x $76 \mathrm{~mm}$ x $71.2 \mathrm{~mm}$ \\
\hline & Number of plates & 30 \\
\hline
\end{tabular}

The refrigerant loop is built assembling a semi-hermetic, variable speed reciprocating compressor, two stainless steel plate heat exchangers (i.e. the condenser and the evaporator) in countercurrent arrangement and two electronic expansion valves, arranged in parallel but with only one of 
them active at a time. For safe and smooth operation of the heat pump, addtional components such as the suction accumulator, the oil separator, with oil sent back to the compressor service port, and the liquid receiver are installed too. The refrigerant loop is controlled acting on the rotational frequency of the compressor shaft and on the superheating at evaporator outlet set-point. In the water + ethylene glycol loop, a variable speed pump, a buffer tank and a three-way valve are used. This loop is controlled acting on pump rotational speed, to set the water + ethylene glycol flow rate to the desired value, and on the three-way valve, to set the water + ethylene glycol temperature at evaporator outlet to the required set-point while the buffer tank allows to reduce the temperature fluctuations and to reach stable testing conditions. The ethylene glycol concentration is $25.4 \%$ by volume that means freezing temperature equal to $260.55 \mathrm{~K}$. Finally, the hot water loop consists of the same components found in the water + ethylene glycol loop and adding an auxiliary chiller. Similarly to the cold loop, the hot water loop is used to set the water flow rate to the desired value, acting on the pump rotational speed, and to set the water temperature at condenser outlet to the required set-point, acting on the three-way valve. Again, the buffer tank allowed to reduce the hot water temperature fluctuations and to reach stable testing conditions. The auxiliary chiller is needed to balance the difference between evaporator and condenser capacities. All the components and connecting pipes are insulated using elastomeric material with reference thermal conductivity equal to $0.037 \mathrm{~W} \cdot \mathrm{m}^{-1} \cdot \mathrm{K}^{-1}$.

The experimental set-up is equipped with instrumentations allowing for the measurement, acquisition and storing of the main parameters such as pressures, temperatures, flow rates and power. The positions of all the measurement devices is shown in Figure 1 whereas their main characteristics are reported in Table 2.

\subsection{Testing procedure}

The experimental procedure used to run each test is the following:

1. At the beginning of each test, the pumps of the cold water+ethylene glycol loop and of the hot water loop are switched on. The rotational frequency of each pump shaft is set to the value required to guarantee the mass flow rates needed by the test. This value is continuously monitored during the test and is adjusted in order to keep the mass flow rate constant. 
Table 2 - Measurement instrumentation range and accuracy.

\begin{tabular}{cccc}
\hline Parameter & Instrument & Range & Accuracy \\
\hline Refrigerant mass flow rate & Coriolis mass flow meter & $0 \mathrm{~kg} \cdot \mathrm{h}^{-1}-300 \mathrm{~kg} \cdot \mathrm{h}^{-1}$ & $\pm 0.15 \%$ r.v. \\
Refrigerant pressure (low side) & Pressure transducer & $0 \mathrm{kPa}-700 \mathrm{kPa}$ & $\pm 0.3 \%$ f.s. \\
Refrigerant pressure (high side) & Pressure transducer & $0 \mathrm{kPa}-4000 \mathrm{kPa}$ & $\pm 0.3 \%$ f.s. \\
Refrigerant temperature & RTD Pt 100 & $243.15 \mathrm{~K}-373.15$ & $\pm 0.1 \mathrm{~K}$ \\
Compressor power & Power transducer & $0 \mathrm{~W}-4000 \mathrm{~W}$ & $\pm 0.2 \%$ f.s. \\
Water mass flow rate & Vortex flow meter & $0.21 \mathrm{~m}^{3} \cdot \mathrm{h}^{-1}-3 \mathrm{~m}^{3} \cdot \mathrm{h}^{-1}$ & $\pm 2 \%$ r.v. \\
Water temperature & RTD Pt 100 & $263.15 \mathrm{~K}-353.15$ & $\pm 0.1 \mathrm{~K}$ \\
\hline
\end{tabular}

2. The compressor is switched on and its shaft rotational frequency is set to the value required by the test. At the same time, the electronic expansion valves begins to modulate its cross section area in order to guarantee a superheating degree at evaporator outlet equal to $5 \mathrm{~K}$.

3. The temperatures of the cold water+ethylene glycol and of the hot water that respectively flow through the evaporator and the condenser begin changing. In both the secondary fluid loops, a PID controller acts on the 3-way valve with the aim of setting the secondary fluid temperature at heat exchanger outlet to the value required by the test. During the test, the PID controllers continuously adjust the 3-way valve position in order to keep the outlet temperatures to the set-point.

4. Once the set-point temperatures at the outlet of the two heat exchangers are reached, the data acquisition starts with a sample rate equal to $1 \mathrm{~s}$. For each of the measured pressures and temperatures, the simple moving average and the standard deviation are calculated considering the last 900 samples.

5. During the test, if the standard deviation of each measured pressure and temperature lies within $\pm 2.5 \mathrm{kPa}$ and $\pm 0.2 \mathrm{~K}$ respectively, the test is considered in steady-state condition and further 900 samples are recorded at $1 \mathrm{~Hz}$ for data analysis .

6. Finally, at the end of the test, the evaporator and the condenser heat transfer rates are calcu- 
lated considering both the refrigerant-side mass flow rate and enthalpies and the water-side mass flow rate and temperatures. If the two values agree within $\pm 4 \%$, the test is considered concluded, otherwise it is repeated.

\subsection{Data reduction and uncertainty analysis}

As stated, the experimental set-up mimics a heat pump. Therefore, the condenser heating capacity is the useful effect and the COP is the performance index.

The condenser heat transfer rate is calculated as the average between the values calculated considering the refrigerant-side and considering the hot water-side value according to the following equation:

$$
\dot{Q}_{C O N D}=\frac{1}{2}\left[\dot{m}_{R}\left(h_{R, I N, C O N D}-h_{R, O U T, C O N D}\right)+\dot{m}_{W} c_{P, W}\left(T_{W, O U T, C O N D}-T_{W, I N, C O N D}\right)\right]
$$

In Eq.(1), the enthalpy of the refrigerant at the evaporator inlet is assumed equal to the enthalpy at condenser outlet since the connecting pipes and the liquid receiver are well insulated. Refprop 9.1 (Lemmon et al., 2013) is used to calculate both the water isobaric heating capacity, as a function of the water average temperature, and the refrigerant enthalpies, as a function of the refrigerant pressures and temperatures.

The coefficient of performance of the water-to-water heat pump is calculated as the ratio between the heat pump heating capacity and the heat pump power consumption. The latter is evaluated neglecting the power consumption of the two secondary fluids pumps and the EXV controller and accounting also for the inverter losses in the measured compressor power:

$$
C O P=\frac{\dot{Q}_{C O N D}}{\dot{W}_{C O M P}}
$$

The uncertainty of each of the directly measured or calculated parameter is estimated according to Moffat (1988). More in detail, the experimental uncertainty of each directly measured variable is calculated as follows: 


$$
u_{x}= \pm \sqrt{u_{x_{I N S T}}^{2}+\left(t_{95} \sigma_{\bar{x}}\right)^{2}}
$$

Similarly, the uncertainty of the generic calculated quantity is estimated using the combined standard uncertainty under the uncorrelated input quantities assumption:

$$
u_{y}= \pm \sqrt{\sum_{i=1}^{N}\left(\frac{\partial y}{\partial x_{i}} u_{x_{I N S T}}\right)^{2}+t_{95}^{2} \sum_{i=1}^{N}\left(\frac{\partial y}{\partial x_{i}} \sigma_{\overline{x_{i}}}\right)^{2}}
$$

\section{Results and discussion}

As stated, in the present work the performance of a water-to-water heat pump that uses R134a, $\mathrm{R} 1234 \mathrm{yf}$ and $\mathrm{R} 1234 \mathrm{ze}(\mathrm{E})$ in a drop-in application is experimentally measured. Table 3 summarises the main properties of the three tested refrigerants.

Table 3 - Main properties of the three tested refrigerants.

\begin{tabular}{cccc}
\hline Parameter & $\mathrm{R} 134 \mathrm{a}$ & $\mathrm{R} 1234 \mathrm{yf}$ & $\mathrm{R} 1234 \mathrm{ze}(\mathrm{E})$ \\
\hline Chemical formula & $\mathrm{CH}_{2} \mathrm{FCF}_{3}$ & $\mathrm{CF}_{3}-\mathrm{CF}=\mathrm{CH}_{2}$ & $\mathrm{C}_{3} \mathrm{H}_{2} \mathrm{~F}_{4}$ \\
Critical pressure & $4059.3 \mathrm{kPa}$ & $3382.2 \mathrm{kPa}$ & $3634.9 \mathrm{kPa}$ \\
Critical temperature & $374.21 \mathrm{~K}$ & $367.85 \mathrm{~K}$ & $382.51 \mathrm{~K}$ \\
Molar mass & $102.03 \mathrm{~g} \cdot \mathrm{mol}^{-1}$ & $114.04 \mathrm{~g} \cdot \mathrm{mol}^{-1}$ & $114.04 \mathrm{~g} \cdot \mathrm{mol}^{-1}$ \\
Normal Boiling Point & $247.08 \mathrm{~K}$ & $243.67 \mathrm{~K}$ & $254.18 \mathrm{~K}$ \\
$c_{P}^{0 *}$ & $80.417 \mathrm{~J} \cdot \mathrm{mol}^{-1} \cdot \mathrm{K}^{-1}$ & $95.713 \mathrm{~J} \cdot \mathrm{mol}^{-1} \cdot \mathrm{K}^{-1}$ & $95.128 \mathrm{~J} \cdot \mathrm{mol}^{-1} \cdot \mathrm{K}^{-1}$ \\
ODP & 0 & 0 & 0 \\
$\mathrm{GWP}_{100}$ (Stocker et al., 2013) & 1300 & $<1$ & $<1$ \\
ASHRAE Classification & $\mathrm{A} 1$ & $\mathrm{~A} 2 \mathrm{~L}$ & $\mathrm{~A} 2 \mathrm{~L}$ \\
\hline
\end{tabular}

* Value at $273.15 \mathrm{~K}$. 
With respect to the baseline refrigerant R134a, it is common knowledge (Molinaroli et al., 2011) that, over the full range of saturation temperature, R1234yf has very similar saturation pressure (the saturation pressures are identical at saturation temperature equal to $314.38 \mathrm{~K}$ ), slightly higher saturated vapour density but lower enthalpy of vaporization. Conversely, R1234ze(E) exhibits lower saturation pressure, lower saturated vapour density whereas its enthalpy of vaporization is lower than that of R134a for saturation temperature below $344.58 \mathrm{~K}$ and higher above this value.

The experimental set-up is charged under test condition 03 in Table 4 considering a superheating at evaporator outlet equal to $5 \mathrm{~K}$ and a subcooling at condenser outlet equal to $3.5 \mathrm{~K}$ as target values. The final charge is $4000 \mathrm{~g}$ for R134a, $4350 \mathrm{~g}$ for R1234yf and $2410 \mathrm{~g}$ for R1234ze(E).

The performance assessment of the use of the two HFOs as substitutes of R134a is carried out considering two different groups of tests as detailed in the following sections.

\subsection{Drop-in tests}

The first group of tests considers a pure drop-in application with the aim of measuring the heat pump heating capacity and performance index without modifying the heat pump operation. Namely, each test is run considering the same rotational frequency of the compressor shaft, the same vapour superheating at the evaporator outlet and keeping constant the temperature of the secondary fluids at the outlet of the evaporator and of the condenser. Due to different heat pump performance with different refrigerants, during these tests the mass flow rates of the secondary fluids that flow through the two heat exchangers are changed. First, these mass flow rates are identified in five different reference conditions in which not only the secondary fluids outlet temperatures, but also the inlet temperatures in the two heat exchangers are set. These testing conditions are testing conditions $03,08,13,18$ ans 23 in Table 4. Once identified, the mass flow rates of the secondary fluids are kept constant in the other tests. The whole experimental conditions used in this first group of tests are reported in Table 4.

Figures 2 - 6 report the results of the heat pump heating capacity and $C O P$ for the five temperatures of the water at the condenser outlet. For each figure, both the heating capacity, on the left-side, and the $C O P$, on the right-side, are plotted against the water-ethylene glycol mixture 
Table 4 - Experimental conditions used during the drop-in tests.

\begin{tabular}{|c|c|c|c|c|c|c|c|c|}
\hline \multirow{2}{*}{ Test } & \multirow{2}{*}{$\begin{array}{c}\text { Compressor } \\
f_{S H A F T}\end{array}$} & \multirow{2}{*}{$\begin{array}{c}\text { Superheating } \\
\qquad \Delta T_{S U P}\end{array}$} & \multicolumn{3}{|c|}{ Evaporator } & \multicolumn{3}{|c|}{ Condenser } \\
\hline & & & $\dot{m}_{G}$ & $T_{G, I N}$ & $T_{G, O U T}$ & $\dot{m}_{W}$ & $T_{W, I N}$ & $T_{W, O U T}$ \\
\hline 01 & $50 \mathrm{~Hz}$ & $5 \mathrm{~K}$ & As Test 03 & $*$ & $268.15 \mathrm{~K}$ & As Test 03 & $*$ & $308.15 \mathrm{~K}$ \\
\hline 02 & $50 \mathrm{~Hz}$ & $5 \mathrm{~K}$ & As Test 03 & $*$ & $273.15 \mathrm{~K}$ & As Test 03 & $*$ & $308.15 \mathrm{~K}$ \\
\hline 03 & $50 \mathrm{~Hz}$ & $5 \mathrm{~K}$ & Identified & $283.15 \mathrm{~K}$ & $278.15 \mathrm{~K}$ & Identified & $303.15^{\circ} \mathrm{C}$ & $308.15 \mathrm{~K}$ \\
\hline 04 & $50 \mathrm{~Hz}$ & $5 \mathrm{~K}$ & As Test 03 & $*$ & $283.15 \mathrm{~K}$ & As Test 03 & * & $308.15 \mathrm{~K}$ \\
\hline 05 & $50 \mathrm{~Hz}$ & $5 \mathrm{~K}$ & As Test 03 & $*$ & $288.15 \mathrm{~K}$ & As Test 03 & $*$ & $308.15 \mathrm{~K}$ \\
\hline 06 & $50 \mathrm{~Hz}$ & $5 \mathrm{~K}$ & As Test 08 & $*$ & $268.15 \mathrm{~K}$ & As Test 08 & $*$ & $318.15 \mathrm{~K}$ \\
\hline 07 & $50 \mathrm{~Hz}$ & $5 \mathrm{~K}$ & As Test 08 & $*$ & $273.15 \mathrm{~K}$ & As Test 08 & $*$ & $318.15 \mathrm{~K}$ \\
\hline 08 & $50 \mathrm{~Hz}$ & $5 \mathrm{~K}$ & Identified & $283.15 \mathrm{~K}$ & $278.15 \mathrm{~K}$ & Identified & $313.15^{\circ} \mathrm{C}$ & $318.15 \mathrm{~K}$ \\
\hline 09 & $50 \mathrm{~Hz}$ & $5 \mathrm{~K}$ & As Test 08 & $*$ & $283.15 \mathrm{~K}$ & As Test 08 & $*$ & $318.15 \mathrm{~K}$ \\
\hline 10 & $50 \mathrm{~Hz}$ & $5 \mathrm{~K}$ & As Test 08 & $*$ & $288.15 \mathrm{~K}$ & As Test 08 & $*$ & $318.15 \mathrm{~K}$ \\
\hline 11 & $50 \mathrm{~Hz}$ & $5 \mathrm{~K}$ & As Test 13 & $*$ & $268.15 \mathrm{~K}$ & As Test 13 & $*$ & $328.15 \mathrm{~K}$ \\
\hline 12 & $50 \mathrm{~Hz}$ & $5 \mathrm{~K}$ & As Test 13 & $*$ & $273.15 \mathrm{~K}$ & As Test 13 & $*$ & $328.15 \mathrm{~K}$ \\
\hline 13 & $50 \mathrm{~Hz}$ & $5 \mathrm{~K}$ & Identified & $283.15 \mathrm{~K}$ & $278.15 \mathrm{~K}$ & Identified & $323.15^{\circ} \mathrm{C}$ & $328.15 \mathrm{~K}$ \\
\hline 14 & $50 \mathrm{~Hz}$ & $5 \mathrm{~K}$ & As Test 13 & $*$ & $283.15 \mathrm{~K}$ & As Test 13 & $*$ & $328.15 \mathrm{~K}$ \\
\hline 15 & $50 \mathrm{~Hz}$ & $5 \mathrm{~K}$ & As Test 13 & $*$ & $288.15 \mathrm{~K}$ & As Test 13 & $*$ & $328.15 \mathrm{~K}$ \\
\hline 16 & $50 \mathrm{~Hz}$ & $5 \mathrm{~K}$ & As Test 18 & $*$ & $268.15 \mathrm{~K}$ & As Test 18 & $*$ & $338.15 \mathrm{~K}$ \\
\hline 17 & $50 \mathrm{~Hz}$ & $5 \mathrm{~K}$ & As Test 18 & $*$ & $273.15 \mathrm{~K}$ & As Test 18 & $*$ & $338.15 \mathrm{~K}$ \\
\hline 18 & $50 \mathrm{~Hz}$ & $5 \mathrm{~K}$ & Identified & $283.15 \mathrm{~K}$ & $278.15 \mathrm{~K}$ & Identified & $333.15^{\circ} \mathrm{C}$ & $338.15 \mathrm{~K}$ \\
\hline 19 & $50 \mathrm{~Hz}$ & $5 \mathrm{~K}$ & As Test 18 & $*$ & $283.15 \mathrm{~K}$ & As Test 18 & $*$ & $338.15 \mathrm{~K}$ \\
\hline 20 & $50 \mathrm{~Hz}$ & $5 \mathrm{~K}$ & As Test 18 & $*$ & $288.15 \mathrm{~K}$ & As Test 18 & $*$ & $338.15 \mathrm{~K}$ \\
\hline 21 & $50 \mathrm{~Hz}$ & $5 \mathrm{~K}$ & As Test 23 & $*$ & $268.15 \mathrm{~K}$ & As Test 12 & $*$ & $348.15 \mathrm{~K}$ \\
\hline 22 & $50 \mathrm{~Hz}$ & $5 \mathrm{~K}$ & As Test 23 & $*$ & $273.15 \mathrm{~K}$ & As Test 23 & $*$ & $348.15 \mathrm{~K}$ \\
\hline 23 & $50 \mathrm{~Hz}$ & $5 \mathrm{~K}$ & Identified & $283.15 \mathrm{~K}$ & $278.15 \mathrm{~K}$ & Identified & $343.15^{\circ} \mathrm{C}$ & $348.15 \mathrm{~K}$ \\
\hline 24 & $50 \mathrm{~Hz}$ & $5 \mathrm{~K}$ & As Test 23 & $*$ & $283.15 \mathrm{~K}$ & As Test 23 & $*$ & $348.15 \mathrm{~K}$ \\
\hline 25 & $50 \mathrm{~Hz}$ & $5 \mathrm{~K}$ & As Test 23 & $*$ & $288.15 \mathrm{~K}$ & As Test 23 & $*$ & $348.15 \mathrm{~K}$ \\
\hline
\end{tabular}


at the evaporator outlet. For the sake of completeness, the calculated uncertainty, as per Eq. (4), is reported too using error bars. Overall, the calculated uncertainty ranges from $\pm 62.31 \mathrm{~W}$ to $\pm 156.91 \mathrm{~W}$ for the heating capacity and from \pm 0.03 to \pm 0.08 for the $C O P$.

Starting from the heating capacity, first, generally, all the tested refrigerants show the wellestablished tendency of increasing the heating capacity with the increase in the secondary fluid temperature at evaporator outlet and with the reduction of the secondary fluid temperature at condenser outlet since these temperatures influence the evaporating temperature and the condensing temperatures respectively. The heating capacity delivered by the heat pump working with R1234yf is slightly lower than that measured with R134a in all the experimental conditions, with reduction in the range $1.51 \%$ to $9.80 \%$. This behaviour arises mainly from the enthalpy difference across the condenser, which is lower for the R1234yf with respect to that of the R134a, due to higher molar mass of the former refrigerant. Indeed, even if the vapour density at compressor suction of R1234yf is higher, leading to slightly higher displaced mass flow rate, the reduced enthalpy difference effect dominates the overall heating capacity production. Considering the R1234ze(E), a substantial reduction of the condenser heat transfer rate is measured in the whole range of the testing conditions. The reduction of the capacity lies in the range $14.92 \%$ to $33.82 \%$ and it is the consequence of a simultaneous reduction of the enthalpy difference across the condenser, as for the R1234yf, and of the refrigerant mass flow rate which, in turn, is related to the lower pressure and density of this refrigerant at compressor suction. Finally, the difference between R134a and $\mathrm{R} 1234 \mathrm{ze}(\mathrm{E})$ heating capacity tends to reduce as the water temperature at condenser outlet increases since R134a is approaching the critical temperature more rapidly than R1234ze(E) which, in turn, leads to a faster reduction of the enthalpy difference across the condenser.

Considering the $C O P$, similarly to the heating capacity, all the tested refrigerants show the well-known increase in the $C O P$ with the increase in the secondary fluid temperature at evaporator outlet, i.e. increase in the evaporating temperature, and with the reduction of the secondary fluid temperature at condenser outlet, i.e. the reduction of the condensing temperature. Similarly to the heating capacity, in all the testing conditions the $C O P$ of the heat pump that operates with R1234yf is slightly lower than the COP measured with R134a, with reduction ranging from $0.33 \%$ to $7.39 \%$. This behaviour is related to the different critical temperature and reference isobaric specific heat of 
R1234yf with respect to R134a. Indeed, the COP of any vapour compression system increases if a high critical temperature and low reference isobaric specific heat refrigerant is used (Domanski et al., 2014). As shown in Table 3, the critical temperature and the reference isobaric specific heat of R1234yf are respectively lower than and higher than those of R134a which, in turn, leads to lower heat pump $C O P$. Vice-versa, quite surprisingly, the trend of the $C O P$ obtained with $\mathrm{R} 1234 \mathrm{ze}(\mathrm{E})$ is different. Indeed, in all the testing conditions, the $C O P$ obtained with $\mathrm{R} 1234 \mathrm{ze}(\mathrm{E})$ is lower than that measured with R134a for water-ethylene glycol temperature at evaporator outlet lower than $278.15 \mathrm{~K}$ and, additionally, the $C O P$ tends to reduce more rapidly for $\mathrm{R} 1234 \mathrm{ze}(\mathrm{E})$ than for R134a with the increase in the water temperature at condenser outlet. This tendency reverses for water-ethylene glycol temperature at evaporator outlet greater than $278.15 \mathrm{~K}$ where the $C O P$ of the heat pump working with $\mathrm{R} 1234 \mathrm{ze}(\mathrm{E})$ is similar or even higher than that obtained with R134a and, again, R1234ze(E) is more sensitive than R134a to the increase in the water temperature at condenser outlet. To explain this behaviour, firstly it must be considered that both the critical temperature and the reference isobaric specific heat of $\mathrm{R} 1234 \mathrm{ze}(\mathrm{E})$ are higher than those of R134a which, generally speaking, may lead to a $C O P$ of a vapour compression system that uses $\mathrm{R} 1234 \mathrm{ze}(\mathrm{E})$ may be higher or lower than that of R134a depending on the operating conditions. Secondly, the higher is the water-ethylene glycol temperature at evaporator outlet, the higher are the evaporating temperature and pressure and, under constant superheating working conditions, the vapour density at compressor suction. This leads to an increase in the refrigerant mass flow rate and of the evaporator heat transfer rate which, in turn, brings about an increase in the temperature difference between the secondary fluid and the evaporating refrigerant that forces the heat transfer since the evaporator heat transfer area is constant. Among the three tested refrigerants, R1234ze(E) is the one that achieves the lowest evaporator heat transfer rate and, hence, the lowest temperature difference that drives the heat transfer and the highest evaporating temperature. As a consequence, the $C O P$ of the heat pump working with $\mathrm{R} 1234 \mathrm{ze}(\mathrm{E})$ increases more rapidly than that obtained with the other refrigerants as shown in Table 5 (only some selected testing conditions are shown).

Overall, the $C O P$ variation with $\mathrm{R} 1234 \mathrm{ze}(\mathrm{E})$ lies in the range $-12.27 \%$ to $+4.32 \%$ and these results confirm the suitability of $\mathrm{R} 1234 \mathrm{ze}(\mathrm{E})$ as working fluid of high temperature heat pumps (Fukuda et al., 2014). 
Table 5 - Difference between the water-ethylene glycol mixture temperature at the evaporator outlet and the evaporating temperature and $C O P$ of the heat pump for some selected testing conditions.

\begin{tabular}{ccccccc}
\hline & \multicolumn{3}{c}{$\left(T_{G, \text { OUT,EVAP }}-T_{E V A P}\right)$} & \multicolumn{3}{c}{$C O P$} \\
Test & R134a & R1234yf & R1234ze(E) & R134a & R1234yf & R1234ze(E) \\
\hline 01 & $3.55 \mathrm{~K}$ & $4.91 \mathrm{~K}$ & $1.98 \mathrm{~K}$ & 3.31 & 3.16 & 3.24 \\
05 & $6.16 \mathrm{~K}$ & $7.35 \mathrm{~K}$ & $4.68 \mathrm{~K}$ & 5.11 & 4.74 & 5.19 \\
11 & $2.80 \mathrm{~K}$ & $4.05 \mathrm{~K}$ & $1.27 \mathrm{~K}$ & 2.29 & 2.28 & 2.18 \\
15 & $5.78 \mathrm{~K}$ & $6.68 \mathrm{~K}$ & $5.49 \mathrm{~K}$ & 3.33 & 3.29 & 3.31 \\
21 & $1.75 \mathrm{~K}$ & $2.50 \mathrm{~K}$ & $0.74 \mathrm{~K}$ & 1.63 & 1.58 & 1.43 \\
25 & $6.65 \mathrm{~K}$ & $7.86 \mathrm{~K}$ & $3.69 \mathrm{~K}$ & 2.21 & 2.17 & 2.29 \\
\hline
\end{tabular}
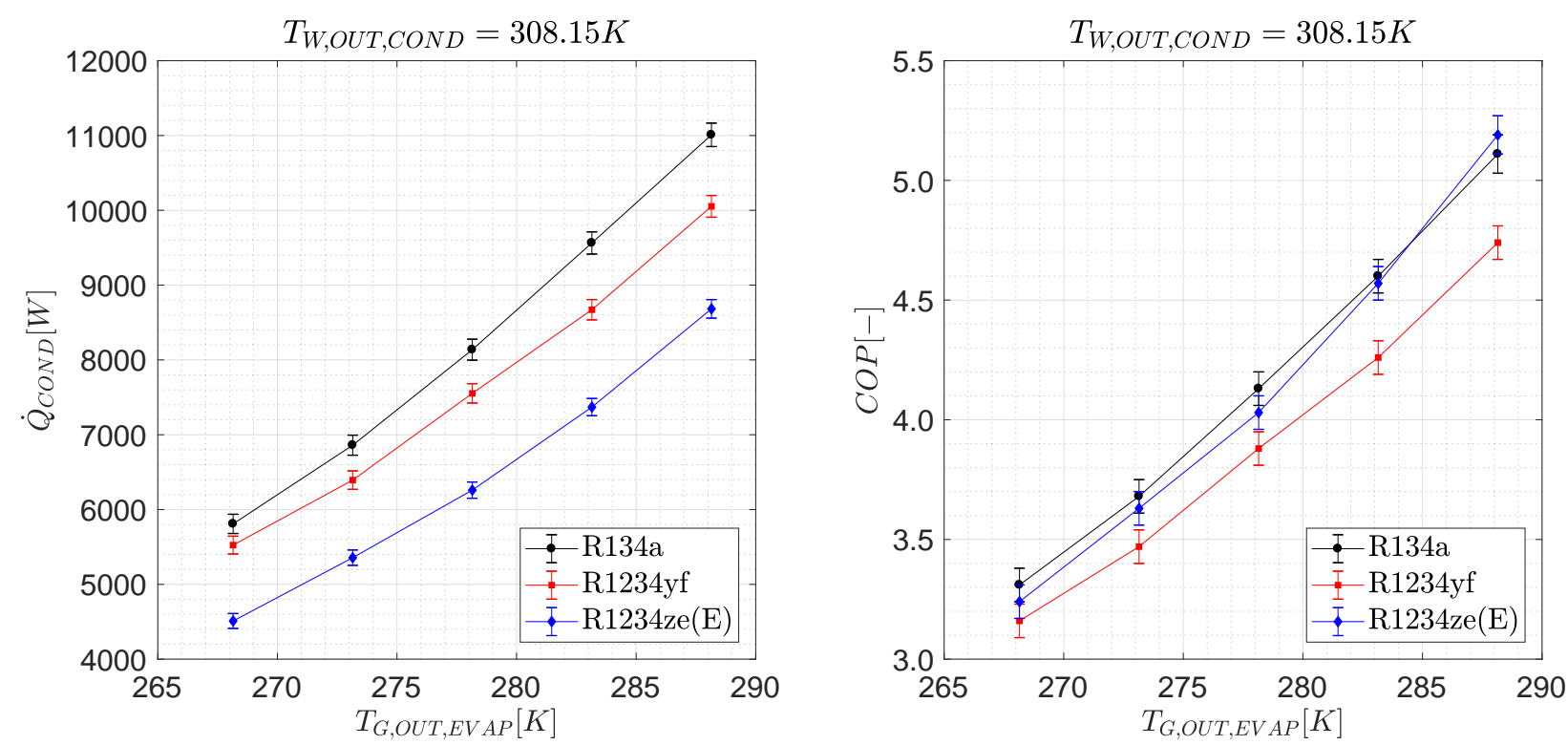

Figure 2 - Heating capacity (left) and COP (right) of the heat pump when the water temperature at the condenser outlet is equal to $308.15 \mathrm{~K}$. 

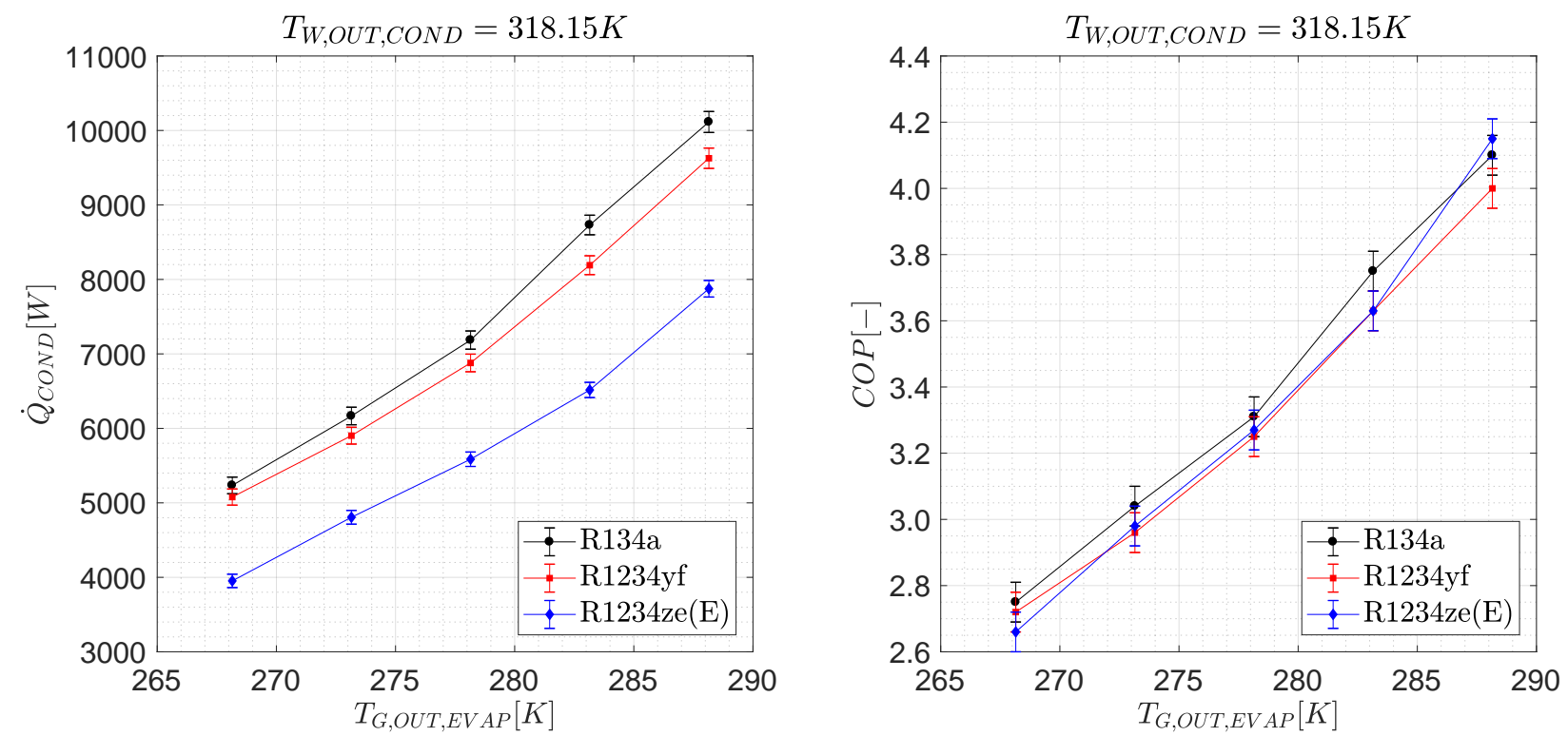

Figure 3 - Heating capacity (left) and COP (right) of the heat pump when the water temperature at the condenser outlet is equal to $318.15 \mathrm{~K}$.
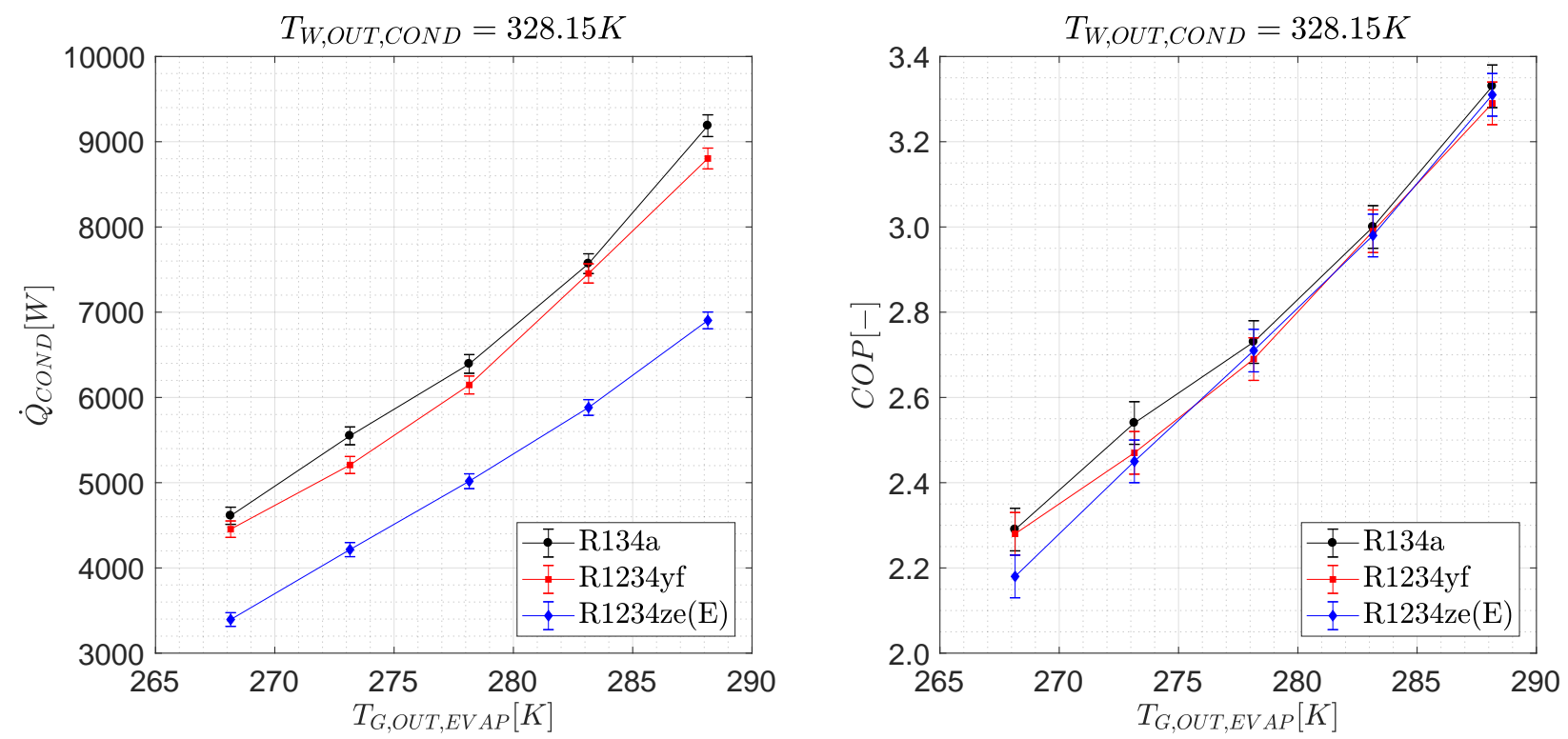

Figure 4 - Heating capacity (left) and COP (right) of the heat pump when the water temperature at the condenser outlet is equal to $328.15 \mathrm{~K}$. 

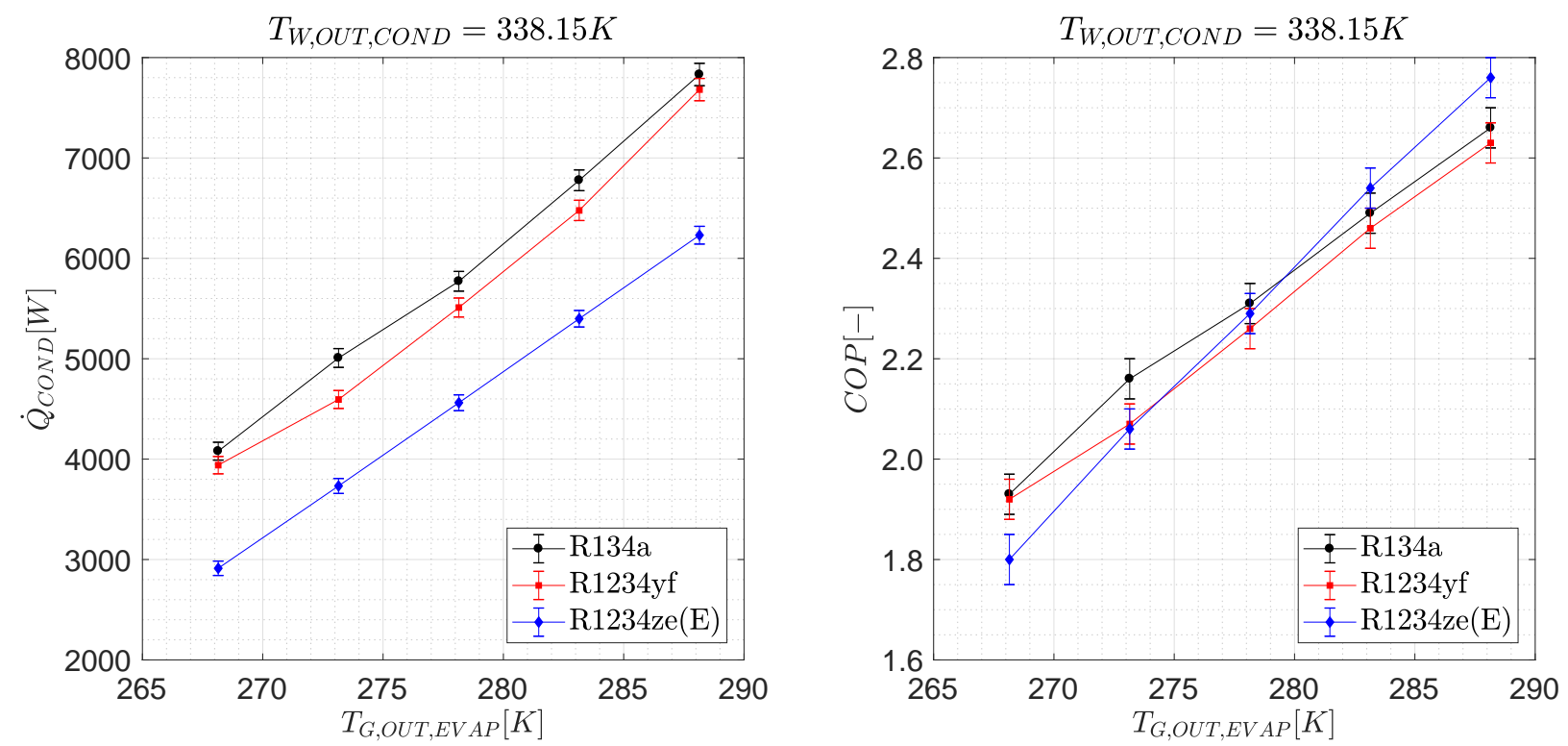

Figure 5 - Heating capacity (left) and COP (right) of the heat pump when the water temperature at the condenser outlet is equal to $338.15 \mathrm{~K}$.
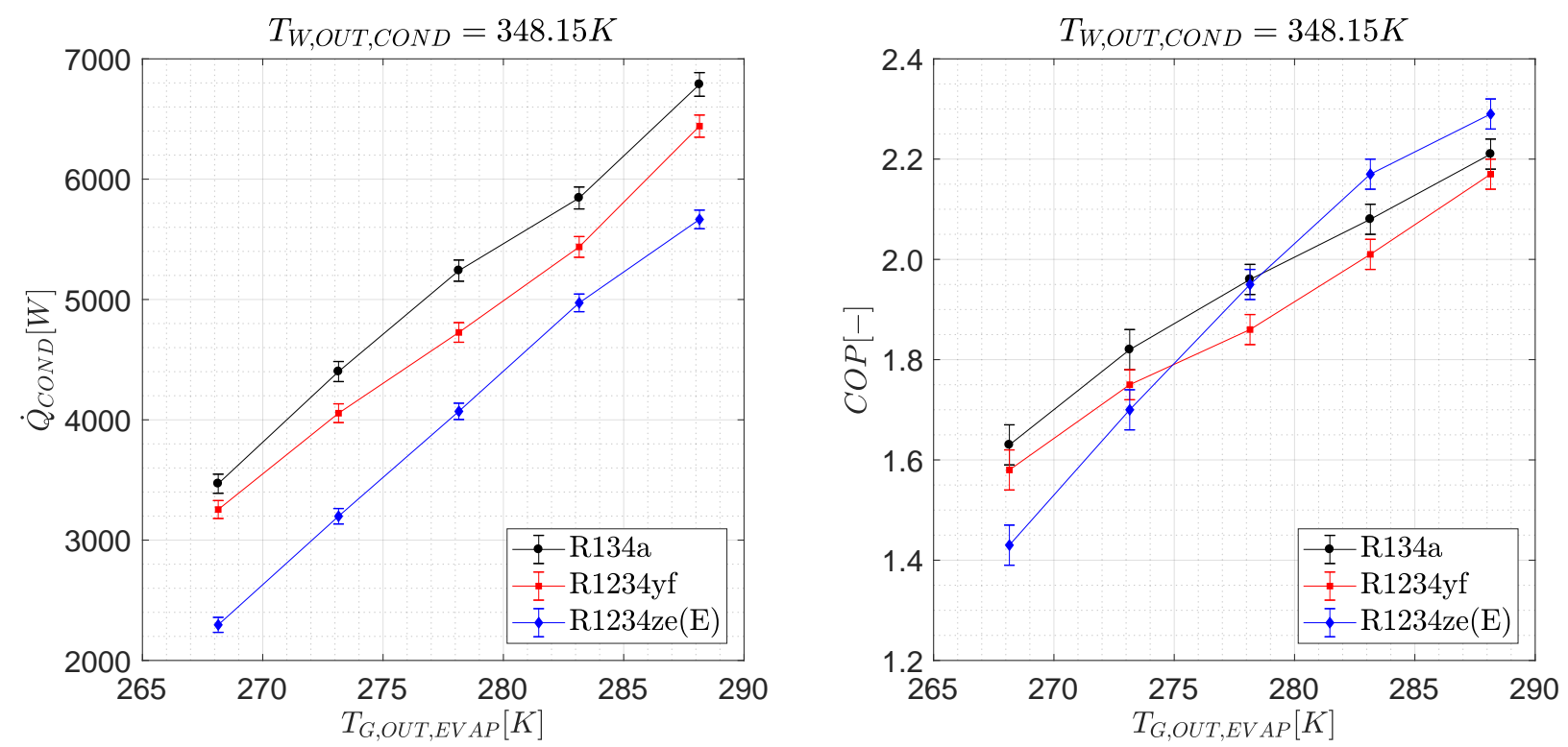

Figure 6 - Heating capacity (left) and COP (right) of the heat pump when the water temperature at the condenser outlet is equal to $348.15 \mathrm{~K}$. 


\subsection{Tests with constant heat pump heating capacity}

The second group of tests is aimed at identifying the compressor shaft rotational frequency to be used with R1234yf and R1234ze(E) to allow the heat pump to deliver the same heating capacity supplied with $\mathrm{R} 134 \mathrm{a}$ at $50 \mathrm{~Hz}$ of compressor shaft rotational frequency. Indeed, as shown in previous section, a reduction of heat pump heating capacity arises with the use of R1234yf and $\mathrm{R} 1234 \mathrm{ze}(\mathrm{E})$ in any working condition and, therefore, it is interesting to evaluate the modification of the compressor shaft rotational frequency required to achieve the same heating capacity and the subsequent variation of the heat pump COP.

The experimental conditions used in this second group of tests are reported in Table 6.

Table 6 - Experimental conditions used during the constant heating capacity tests.

\begin{tabular}{ccccccccc}
\hline & Compressor & Superheating & \multicolumn{3}{c}{ Evaporator } & \multicolumn{3}{c}{ Condenser } \\
Test & $f_{S H A F T}$ & $\Delta T_{S U P}$ & $\dot{m}_{G}$ & $T_{G, I N}$ & $T_{G, O U T}$ & $\dot{m}_{W}$ & $T_{W, I N}$ & $T_{W, O U T}$ \\
\hline 26 & Identified & $5 \mathrm{~K}$ & Identified & $283.15 \mathrm{~K}$ & $278.15 \mathrm{~K}$ & As R134a Test 03 & $303.15^{\circ} \mathrm{C}$ & $308.15 \mathrm{~K}$ \\
27 & Identified & $5 \mathrm{~K}$ & Identified & $283.15 \mathrm{~K}$ & $278.15 \mathrm{~K}$ & As R134a Test 08 & $313.15^{\circ} \mathrm{C}$ & $318.15 \mathrm{~K}$ \\
28 & Identified & $5 \mathrm{~K}$ & Identified & $283.15 \mathrm{~K}$ & $278.15 \mathrm{~K}$ & As R134a Test 13 & $323.15^{\circ} \mathrm{C}$ & $328.15 \mathrm{~K}$ \\
29 & Identified & $5 \mathrm{~K}$ & Identified & $283.15 \mathrm{~K}$ & $278.15 \mathrm{~K}$ & As R134a Test 18 & $333.15^{\circ} \mathrm{C}$ & $338.15 \mathrm{~K}$ \\
30 & Identified & $5 \mathrm{~K}$ & Identified & $283.15 \mathrm{~K}$ & $278.15 \mathrm{~K}$ & As R134a Test 23 & $343.15^{\circ} \mathrm{C}$ & $348.15 \mathrm{~K}$ \\
\hline
\end{tabular}

Figure 7 reports the rotational frequencies of the compressor shaft needed to deliver the same heating capacity supplied with R134a (left) and the heat pump performance index (right) as a function of the water temperature at condenser outlet. The frequency of the heat pump working with R134a is reported too for reference. Again, the overall uncertainty is reported for both parameters. The uncertainty of the shaft rotational frequency is equal to $\pm 1 \mathrm{~Hz}$ while the calculated uncertainty of the $C O P$ ranges from \pm 0.03 to \pm 0.07 .

As it is possible to see, the heat pump may provide the same heating capacity of the baseline refrigerant only if the shaft rotational frequency is increased. A slight increase ranging between $6 \%$ and $16 \%$ is found when R1234yf is used, whereas a substantial increase spanning from $32 \%$ to $50 \%$ is needed when the heat pump works with $\mathrm{R} 1234 \mathrm{ze}(\mathrm{E})$. These results are consistent with those reported in previous studies on refrigerating systems (Jankovic et al., 2015; Mota-Babiloni 
et al., 2017) and may be interpreted considering the results discussed in Section 3.2. Indeed, looking at R1234yf first, the difference between the heating capacity delivered by the heat pump using R134a and R1234yf is low and, consequently, the increase in compressor shaft rotational frequency required to increase the refrigerant mass flow rate and level off the heating capacity is small. On the other hand, with the use of $\mathrm{R} 1234 \mathrm{ze}(\mathrm{E})$, a very high heating capacity reduction arises which, in turn, forces a large increase in the refrigerant mass flow rate, i.e. in the compressor shaft rotational frequency, to restore the heating capacity at R134a level. Additionally, it is worth noting that the increase in the shaft rotational frequency exhibits a decreasing trend with R1234ze(E) whereas it is nearly constant for R1234yf, with the only exception of the point at $T_{W, O U T, C O N D}$ $=348.15 \mathrm{~K}$ where a steep increase is found. This behaviour may be explained considering that as the water temperature at condenser outlet increases, the condensing temperature increases too approaching the critical temperature and this leads to a reduction of the refrigerant enthalpy difference across the condenser. Compared to R134a, R1234yf exhibits lower critical temperature and lower enthalpy of vaporisation over the full range of saturation temperature suffering from the above-mentioned increase in condensing temperature more than the baseline refrigerant. As a result, it requires a steep increase in the shaft rotational frequency to restore the heating capacity at R134a level when the maximum water temperature at condenser outlet operating condition is considered. Additionally, this operating point is out of the envelope of the compressor, since the condensing temperature is higher than the maximum allowed condensing temperature, which is equal to $353.15 \mathrm{~K}$. Vice-versa $\mathrm{R} 1234 \mathrm{ze}(\mathrm{E})$ shows a critical temperature higher than that of $\mathrm{R} 134 \mathrm{a}$ and, as stated before, its enthalpy of vaporization is lower than that of R134a for saturation temperature below $344.58 \mathrm{~K}$ and higher above this value. Therefore, as the water temperature at condenser outlet increases, the increase of R1234ze(E) mass flow rate required to level off the heating capacity reduces since the enthalpy difference across the condenser is getting similar to, or even higher than, that of R134a. It is worth specifying that the rotational frequency of compressor shaft with R1234ze(E) is anyway higher than that obtained with R134a because the former refrigerant has a lower vapour density at compressor suction with respect to the latter.

Finally, the $C O P$ reduces as the rotational frequency increases. The reduction spans the range $2.77 \%$ to $7.38 \%$ when R1234yf is used and the range $1.25 \%$ to $18.11 \%$ when the heat pump op- 
erates with R1234ze(E). This reduction arises from the increase in the shaft rotational frequency that causes an increase in the refrigerant mass flow rate which, in turn, forces the evaporating temperature to reduce and the condensing temperature to increase to allow the heat transfer in the heat exchangers. As a result, the evaporating and condensing pressures separate and the COP reduces. It is interesting to point out that the larger reductions are found when the water temperature at condenser outlet are low, i.e. when the increase in shaft rotational frequency is maximum as per Figure 7. In these working condition the $C O P$ reduction of the R1234ze(E) system is so high that it performs worse than the R1234yf system, but the opposite happens when the water temperature at condenser outlet increases since the condensing temperature of the R1234yf is approaching the critical temperature as previously discussed.
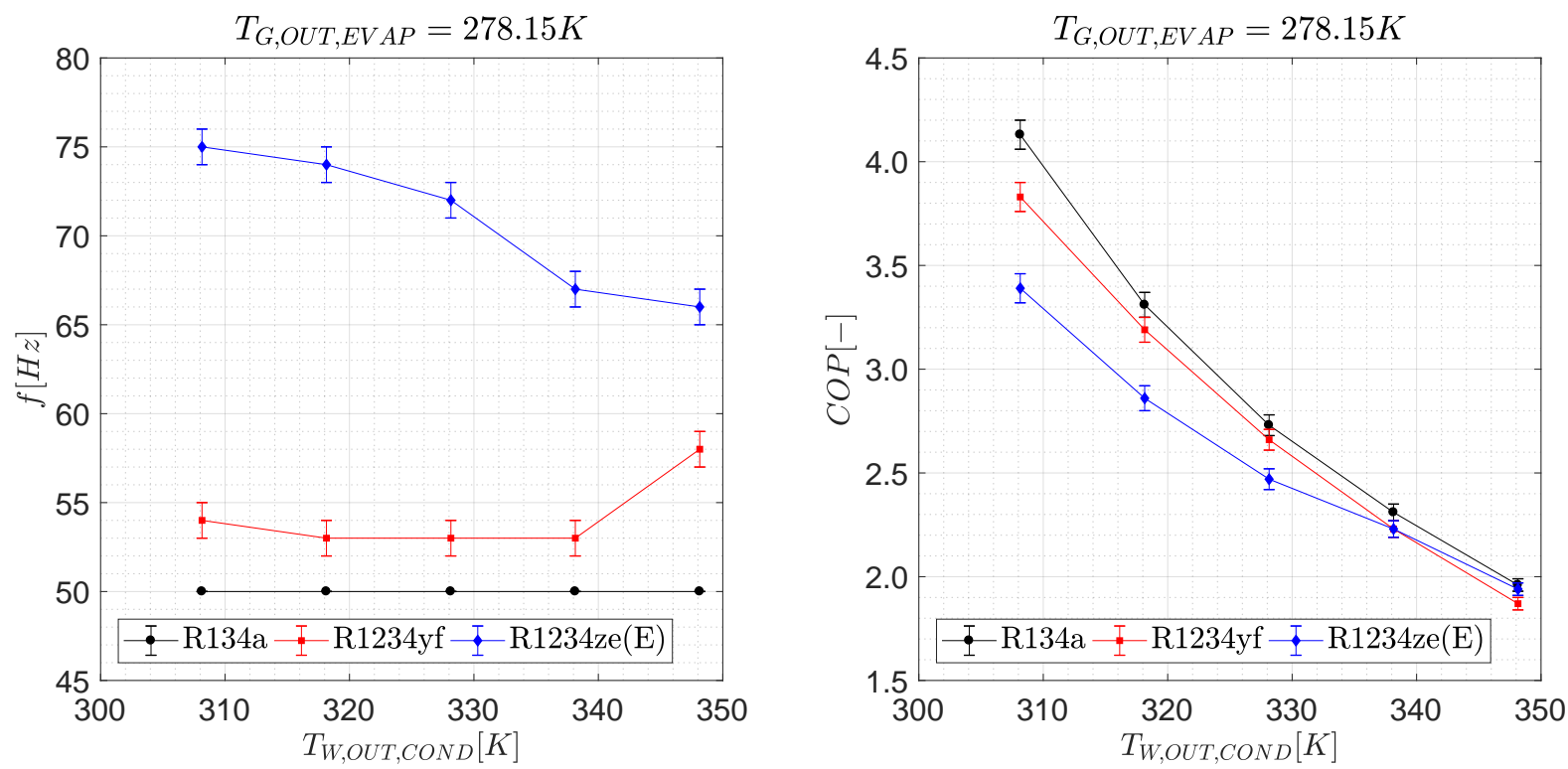

Figure 7 - Rotational frequency of the compressor shaft (left) needed to achieve the same R134a heating capacity and COP (right) of the heat pump when the glycol temperature at the evaporator outlet is equal to $278.15 \mathrm{~K}$.

\section{Conclusions}

In the present paper, the results of an experimental study carried out to assess the performance of the use of R134a and its low GWP alternatives R1234yf and R1234ze(E) in a water-to-water heat pump in a drop-in application are discussed. 
The heat pump is firstly tested with R134a, to establish the baseline performance, and, then, is tested with the above-mentioned HFO refrigerants under the same working conditions, i.e. same rotational frequency of the compressor shaft and same temperatures of the secondary fluids at the evaporator and condenser outlets. The results show that the use of R1234yf leads to a slight capacity reduction, in the range $1.51 \%$ to $9.80 \%$, and a COP reduction, in the range $0.33 \%$ to $7.39 \%$ while with the use of $\mathrm{R} 1234 \mathrm{ze}(\mathrm{E})$ a substantial capacity reduction, in the range $14.92 \%$ to $33.82 \%$, and COP reduction or improvement, in the range $-12.27 \%$ to $+4.32 \%$, are found. Overall, R1234yf seems most suitable for R134a substitution in low and medium temperature heat pumps, whereas R1234ze(E) seems most suitable for high temperature heat pumps.

Additional tests are carried out to find the rotational frequency of the compressor shaft that allow the heat pump working with R1234yf and R1234ze(E) to supply the same baseline heating capacity. An increase in the compressor shaft rotational frequency in the range $6 \%$ and $16 \%$ and $32 \%$ to $50 \%$ is respectively found with R1234yf and R1234ze(E), but subsequent reductions of heat pump COP spanning the range $2.77 \%$ to $7.38 \%$ and $1.25 \%$ to $18.11 \%$ arise with the use of the aforementioned HFOs.

\section{Acknowledgements}

The financial support of MIUR through the program PRIN 2015 (Grant Number 2015M8S2PA) is greatly acknowledged. The company Frascold S.p.A. is acknowledged for providing the compressor used in the experimental campaign. The company Rivoira Refrigerants S.r.l. is acknowledged for providing the sample of R1234yf. Eng. Francesco Bocchinfuso is acknowledged for his participation in the experimental campaign.

\section{References}

Devecioglu, A., Oruç, V., 2018. Improvement on the energy performance of a refrigeration system adapting a plate-type heat exchanger and low-GWP refrigerants as alternatives to R134a. Energy 155, 105 - 116. doi:http://doi.org/10.1016/j.energy.2018.05.032.

Domanski, P., Brown, J., Heo, J., Wojtusiak, J., McLinden, M., 2014. A thermodynamic analysis of refrigerants: Performance limits of the vapor compression cycle. Int. J. Refrigeration 38, $71-79$. doi:http://dx.doi.org/10.1016/j.ijrefrig.2013.09.036. 
European Union, 2014. Regulation (EU) No 517/2014 of the European Parliament and the EUouncil of 16 April 2014 on fluorinated greenhouse gases and repealing Regulation (EC) No 842/2006. Off. J. Eur. Union 150, 195 - 230.

Fukuda, S., Kondou, C., Takata, N., Koyama, S., 2014. Low GWP refrigerants R1234ze(E) and R1234ze(Z) for high temperature heat pumps. Int. J. Refrigeration 40, 161 - 173. doi:http://dx.doi.org/10.1016/j.ijrefrig.2013.10.014.

Jankovic, Z., Sieres Atienza, J., Martínez Suárez, J., 2015. Thermodynamic and heat transfer analyses for R1234yf and R1234ze(E) as drop-in replacements for R134a in a small power refrigerating system. App. Therm. Eng. 80, 42 - 54. doi:http://dx.doi.org/10.1016/j.applthermaleng.2015.01.041.

Jarall, S., 2012. Study of refrigeration system with HFO-1234yf as a working fluid. Int. J. Refrigeration 35, $1668-$ 1677. doi:http://dx.doi.org/10.1016/j.ijrefrig.2012.03.007.

Lemmon, E., Huber, M., McLinden, M., 2013. NIST Standard Reference Database 23: Reference Fluid Thermodynamic and Transport Properties-REFPROP, Version 9.1. National Institute of Standards and Technology, Standard Reference Data Program, Gaithersburg.

Moffat, R., 1988. Describing the uncertainties in experimental results. Exp. Therm. Fluid Sci. 1, 3 - 17. doi:http://doi.org/10.1016/0894-1777(88)90043-X.

Molinaroli, L., Joppolo, C., Pasini, A., 2011. An assessment of the potential use of refrigerants R-1234yf and R1234ze in stationary chillers and heat pumps, in: Proceedings of the 48th AICARR International Congress, Baveno, Italy, pp. 485-496.

Molés, F., Navarro-Esbrí, J., Peris, B., Mota-Babiloni, A., Barragán-Cervera, A., $2014 . \quad$ Theoretical energy performance evaluation of different single stage vapour compression refrigeration configurations using R1234yf and R1234ze(E) as working fluids. Int. J. Refrigeration 44, $141-150$. doi:http://dx.doi.org/10.1016/j.ijrefrig.2014.04.025.

Mota-Babiloni, A., Navarro-Esbrí, J., Mendoza-Miranda, J., Peris, B., 2017. Experimental investigation of system modifications to increase R1234ze(E) cooling capacity. App. Therm. Eng. 111, 786 - 792. doi:http://dx.doi.org/10.1016/j.applthermaleng.2016.09.175.

Mota-Babiloni, A. Navarro-Esbrí, J., Barragán, Á., Molés, F., 2014. Drop-in energy performance evaluation of R1234yf and R1234ze(E) in a vapor compression system as R134a replacements. App. Therm. Eng. 71,259 2665. doi:http://dx.doi.org/10.1016/j.applthermaleng.2014.06.056.

Mota-Babiloni, A. Navarro-Esbrí, J., Barragán-Cervera, Á., Molés, F., Peris, B., 2015. Drop-in analysis of an internal heat exchanger in a vapour compression system using R1234ze(E) and R450A as alternatives for R134a. Energy 90, 1636 - 1644. doi:http://dx.doi.org/10.1016/j.energy.2015.06.133.

Navarro-Esbrí, J., Mendoza-Miranda, J., Mota-Babiloni, A., Barragán-Cervera, A., Belman-Flores, J., 2013a. Experimental analysis of R1234yf as a drop-in replacement for R134a in a vapor compression system. Int. J. Refrigeration 36, 870 - 880. doi:http://dx.doi.org/10.1016/j.ijrefrig.2012.12.014.

Navarro-Esbrí, J., Molés, F., Barragán-Cervera, Á., 2013b. Experimental analysis of the internal heat exchanger 
influence on a vapour compression system performance working with R1234yf as a drop-in replacement for R134a. App. Therm. Eng. 59, 153 - 161. doi:http://dx.doi.org/10.1016/j.applthermaleng.2013.05.028.

Nawa, K., Shen, B., Elatar, A., Baxter, V., Abdelaziz, O., 2017. R1234yf and R1234ze(e) as lowGWP refrigerants for residential heat pump water heaters. Int. J. Refrigeration 82, 348 - 365 . doi:http://dx.doi.org/10.1016/j.jirefrig.2017.06.031.

Sethi, A., Becerra, E., Yanna Motta, S., 2016. Low GWP R134a replacements for small refrigeration (plug-in) applications. Int. J. Refrigeration 66, 64 - 72. doi:http://dx.doi.org/10.1016/j.ijrefrig.2016.02.005.

Stocker, T., Qin, D., Plattner, G.K., Tignor, M., Allen, S., Boschung, J., Nauels, A., Xia, Y., Bex, V., Midgley, P.e., 2013. Climate Change 2013: The Physical Science Basis. Contribution of Working Group I to the Fifth Assessment Report of the Intergovernmental Panel on Climate Change. Cambridge University Press, Cambridge, United Kingdom and New York, NY, USA.

Sánchez, D., Cabello, R., Llopis, R., Arauzo, I., Catalán-Gil, J., Torrella, E., 2017. Energy performance evaluation of R1234yf, R1234ze(e), R600a, R290 and R152a as low-GWP R134a alternatives. Int. J. Refrigeration 74, 269 282. doi:http://dx.doi.org/10.1016/j.jirefrig.2016.09.020.

United Nations, 2016. The amendment to the Montreal Protocol agreed by the Twenty-Eighth Meeting of the Parties (Kigali, 10-15 October 2016).

Zilio, C., Brown, J., Schiochet, G., Cavallini, A., 2011. The refrigerant R1234yf in air conditioning systems. Energy 36, 6110 - 6120. doi:http://dx.doi.org/10.1016/j.energy.2011.08.002. 